\title{
Discussion on Linyi University's School-based Curriculum Construction Based on the Subject of Intangible Cultural Heritage*
}

\author{
Pengcheng Shao \\ Linyi University Feixian Campus \\ Linyi, China
}

\begin{abstract}
Intangible cultural heritage school-based curriculum construction is with far-reaching and important significance in carrying out and strengthening the excellent traditional culture education of college students, inspiring the national pride, constructing a harmonious campus, and improving the effectiveness of moral education, as well as carrying out specialty teaching, enhancing quality education and expanding the influence of colleges and universities, etc. The intangible cultural heritage-based curriculum construction should highlight the characteristics of local folk culture, and focus on regions, and learning comprehensiveness, practicality and openness. The intangible cultural heritage curriculum system construction should uphold the principles of science, practicality and development. The intangible cultural heritage school-based curriculum construction should not only meet the need of technique heritance of the intangible cultural heritage, but also combine the theory with practice to apply the learned knowledge into practice, thus to ultimately realize the curriculum modularization. Specifically, the following strategies are adopted: providing a platform for regional cultural heritage; developing curriculum to lay the foundation for heritance of intangible cultural heritage; taking humanities education as the main line and practical activities as the engine to achieve the heritance and development of intangible cultural heritage; taking teachers construction as the guarantee to escort the heritance of the regional culture, intangible cultural heritage; using new media technologies to expand protection and heritance path. In addition, the government and enterprises should work together to promote regional economic development. Intangible cultural heritage curriculum should be evaluated in terms of curriculum and professional skills under the guidance of fundamental, practical and cutting-edge principles.
\end{abstract}

Keywords-Linyi University; intangible cultural heritage; school-based curriculum;construction

\section{INTRODUCTION}

More comprehensive national strength that takes cultural soft power as its important content is required to realize Chinese dream of the great rejuvenation of the Chinese nation. How to cultivate the top innovative talents who inherit and carry forward the excellent traditional culture, as

*Fund Project: Special Program of Art Education in Shandong Province in 2017 (YJ17110060) well as conscientiously and effectively practice the core values of socialism is a new task in construction of intangible cultural heritage school-based curriculum in the new situation.

\section{SIGNIFICANCE OF CURRICULUM CONSTRUCTION}

\section{A. To Inspire National Pride, Building a Harmonious Campus, Improving the Moral Education Effectiveness}

Each intangible cultural heritage is the brand of the history, by taking Linyi as an example there are wicker-made products, Lu ink-stones, clay sculpture, wood spin toys, Liu Chin opera, woodcut new year paintings, dragon lanterns and many other types. During the contact with these historical and cultural heritages, the students have been with deepening love of their hometown, together with continuous increase in the national pride. The dissemination of excellent traditional culture enables students to behave politely; and they have a correct understanding of the country, society and life; this not only purifies the mind but also cultivates sentiments; and their cultural quality, moral standards and awareness of honesty and polite have been enhanced accordingly, and actual effects have been achieved in moral education work.

\section{B. To Carry Out Characteristic Teaching, Strengthening the Quality Education, Expanding College/University Influence}

Local colleges and universities should give full play to their own advantages, and create highlights, thus to highlight the characteristics. The students' cultural awareness of intangible cultural heritage protection has been improved through the intangible cultural heritage curriculum, more importantly the contents of local colleges and universities have been enriched accordingly. Furthermore, intangible cultural heritage curriculum helps to achieve the goal of cultivating people in local college education, thereby enhancing school's core competitiveness. The intangible cultural heritage inheritors can become an important part of the teacher structure of double-qualified teachers in local colleges and universities, thus to expand social influence of colleges and universities. 
C. The Construction of Intangible Cultural Heritage School-based Curriculum Is an Important Means to Carry Out Excellent Traditional Culture and Education of College Students

The intangible cultural heritage is an important representative of excellent traditional Chinese culture, and it's an important part of students' education of the socialist core values. The important measures of the school reform and development, such as the construction of core qualities, training of innovative talents, distinctive development and curriculum reform and others also have a strong demand for the inheritance of the intangible cultural heritage.

\section{The Construction of Intangible Cultural Heritage} School-based Curriculum Is the Objective Needs for Strengthening Excellent Traditional Culture Education of College Students

The excellent traditional culture is the core of inheriting national spirit. The spirit of struggle, patriotism, sense of responsibility, sacrifice, innovative thinking, morality and values, and others contained in the traditional culture have always been the spiritual impetus for the Chinese nation to make progress. School education is the key to the heritance of the national spirit. As successors to the cause of socialism with Chinese characteristics, college students are the hope of inheriting the cultural origins and shaping the soul of the nation.

\section{PHILOSOPHY, PRINCIPLES AND GOALS OF CURRICULUM CONSTRUCTION}

\section{A. Basic Concept of Curriculum Construction}

China is a multi-ethnic and multicultural country with a long history of 5,000 years. There are huge differences in education, economy, culture and other areas in all regions and ethnic groups. This determines that higher education should follow the values of plural cultures and actively embody plural cultures. It's essential to follow the concept of multicultural curriculum to conceive the layout and design courses with local characteristics, thus to promote the folk culture. Specific ideas are:

- To highlight the characteristics of local folk culture of local colleges and universities, focusing on the regions.

The curriculum construction takes Qilu folk culture with its characteristics and influences as the basic content, advocating inquiry learning, which also gives the consideration to students' multicultural education.

- To focus on learning comprehensiveness, practicality and openness.

The curriculum is aimed at improving college students' cultural accomplishment and inheriting Qilu culture. In the course of its design and implementation, the curriculum relies on comprehensive humanities and arts practice with Qilu characteristics to focus on collaborative teaching with other disciplines, so that the students can learn knowledge, developing ability and improving quality in the process of participating in, experiencing and feeling, thus to make the learning process full of inquiry, practicality, and the students can fully feel the characteristics and values of Qilu culture.

\section{B. Principles of Curriculum Construction}

Based on the concept of "ability-based" curriculum, the intangible cultural heritage curriculum system construction adheres to the principle of science; improving the overall quality, adhering to the principle of practicality; forming the professional ability, adhering to the principle of development; forming the principle of the core competencies.

\section{Curriculum Construction Goals}

- To meet the needs of technique heritance of the intangible cultural heritage

The intangible cultural heritage is different from that of traditional mentoring in the education heritance at the local colleges and universities. There are a large number of audiences in the institution heritance education, which requires a scientifically sound curriculum system. This requires that the successors and the faculty work together to analyze the basic knowledge required for mastery of skills according to the content of the intangible cultural heritage and the experience of the successors, as well as the scalability knowledge necessary for the skills heritance and development, thus to determine the relevant curriculum on this basis.

- To combine the theory with practice, thus to apply learned knowledge into practice

It's difficult to adapt to the long-term development of the industry and the needs of the students themselves by only emphasizing the operational skills. The setting of intangible cultural heritage should focus on combining the theory with practice, paying attention to the improvement of students' comprehensive qualifications, highlighting the cultivation of the students' ability to apply knowledge and skills, thus to enable students to quickly adapt to changes in professional positions.

\section{- Modularization of curriculum form}

The education of intangible cultural heritage in local colleges and universities focuses on heritance of technical skills. The three major modules of professional basic curriculum, core courses for skills and comprehensive practice courses are formed by properly integrating the relevant courses. Courses modules are relatively independent and embedded in each other, which are conducive to students' grasp of intangible cultural heritage skills and cultivation of application skills. 


\section{STRATEGY OF CURRICULUM CONSTRUCTION}

A. To Establish Main Heritance Position for Intangible Cultural Heritage, thus to Provide a Platform for the Regional Cultural Heritage

The establishment of school's subordinate unit intangible cultural heritage exhibition experience hall, thus to provide the position for intangible cultural heritage education. Experience Hall can be divided into curriculum construction development center, exhibition and exchange center for works, interaction, participation and experience center, and R\&D creative promotion center. The main task of curriculum construction development center is to develop intangible cultural heritage courses, and exhibition and exchange center for works is to offer position for exhibiting intangible cultural heritage works, interaction, participation and experience center is to provide the students with the platform for them to have the close contact with intangible cultural heritage culture, $R \& D$ creative promotion center provides students with creative venues, promoting the designed works, so that the works turn into commodities.

\section{B. By Taking Curriculum Development as a Breakthrough,} thus to Lay Foundation for the Heritance of the Regional Culture, Intangible Cultural Heritage

The experts, scholars and folk artists are organized to select, organize the intangible cultural heritage, developing Cultural Overview of Linyi Intangible Cultural Heritage, Yuncheng Wood Rotating Toys, Clay Sculpture Culture and Skills and other intangible cultural heritage courses and school-based teaching materials that are with local characteristics of Linyi. The building of a curriculum system, in-depth development of curriculum, thus to make teachers and students have a basis for relying on, and the curriculum development to be more practical, thereby promoting the combination of heritance of the intangible cultural heritage and professional construction.

\section{To Take Humanities Education as the Main Line, thus to Create a True and Beautiful Campus Culture Atmosphere of Truth and Beauty}

The launching of heritance activities of the intangible cultural heritage can continue to create a true, good, and beautiful, upper campus culture atmosphere. The exhibition and experience hall of intangible cultural heritage should be taken as a platform to set up a studio for the successors of intangible cultural heritage, and encourage masters to grant arts to the learners, together with the creation of works, transformation of the promotion results. The intangible cultural heritage achievements exhibition activities are carried out, and folk artists are invited to grant arts in campus, and the theatrical performances, special reports are organized. Furthermore, paper-cut arts associations, Dragon Lights Association and other student associations should be combined, thus to create the brand associations by combining with student activities.

\section{To Take the Practical Activities as an Engine to Achieve the Heritance and Development of the Regional Culture, and Intangible Cultural Heritage}

The combination of the province's "Challenge Cup" series of activities, and series activities of investigation in Shandong, thus to mobilize students to carry out social surveys, and collect intangible cultural heritage projects around the province, thereby deepening the students' understanding of the local intangible cultural heritage. Young volunteers are a beautiful landscape of the new era, and their passion and enthusiasm can provide more volunteer services for the protection of the intangible cultural heritage, thus the normal development of the intangible cultural heritage protection can be promoted with practical actions.

\section{E. To Take Teachers Construction as a Guarantee for the Preservation of Regional Culture and Intangible Cultural Heritage}

According to the demand of the professional construction and development in local colleges and universities, the teachers are sent to visit the field to understand the local intangible cultural heritage projects and the corresponding heritance. In addition, intangible cultural heritage successors are hired as the part-time teachers, professional leaders, various forms are used for training on-the-job teachers, and the successors are encouraged to bring related projects to schools and interact with students, so as to provide them with knowledge and skill assistance for the systematic and normal construction of cultural heritage curriculum in Linyi university, escorting heritance of regional culture and intangible cultural heritage.

\section{F. Taking New Media Technology as a Means to Actively Expand the Channels of Protection and Heritance}

Playing the role of the new media, mobile newspaper, blog, WeChat, QQ group and other ways are adopted to promote intangible cultural heritage, thus to maintain close contact with the students at any time. The school website can also set up advocacy knowledge homepage for intangible cultural heritage, which can be used to introduce cultural heritage protection knowledge, and advocate various national and provincial policies of intangible cultural heritage, playing all kinds of videos for intangible cultural heritage protection.

\section{G. The Government, Enterprise and School Should Work together to Promote the Development, thus to Promote Regional Economic Development}

The heritance of the intangible cultural heritage will be benefited in the future, and the intangible cultural heritage curriculum construction in colleges and universities is its intellectual and information support. The entrance of intangible cultural heritage into school can well achieve the cooperation with enterprises, thus to provide greater market and stage for the development of intangible cultural heritage, and ultimately promote the development of regional economy, thereby injecting the vitality for the intangible cultural heritage protection. For example, Linyi University 
can take the lead in setting up grass weaving associations, clay associations to make contributions to the heritance and innovation of intangible cultural heritage, cultivation of the professionals while meeting the needs of enterprises.

\section{CONSTRUCTION OF CURRICULUM EVALUATION SYSTEM}

\section{A. Principles Should Be Followed for Intangible Cultural Heritage Curriculum Evaluation System}

Promoting the learning by evaluation can play an orientation role in assessment. Assessment is a means, while learning promotion is fundamental purpose. Intangible cultural heritage curriculum evaluation should closely follow the training objectives, and strictly abide by the fundamental, practical and cutting-edge principles.

\section{- Fundamental principle}

Only the higher education lays a solid foundation of comprehensive qualifications for students, making students possess skilled professional skills, can those students meet the diverse needs of the applied talents in the industrial market. For intangible cultural heritage curriculum, the heritance and development of intangible cultural heritage technique itself is carried out in a profound traditional cultural atmosphere. It's difficult to further penetrate the technique heritance without a solid foundation of comprehensive qualities.

\section{- Practical principle}

The practicality is taken as benchmark of assessment, and strengthening assessment of students' practice process practice can better play the "baton" role of the assessment, guiding students to apply learned knowledge into practice, consciously strengthening the overall quality and practical ability.

\section{- Cutting-edge principle}

With the rapid development of science and technology, local colleges and universities should grasp or even lead the trend of technological development in regional cultural industries, thus to meet the needs of society and remain invincible. Assessment follows the cutting-edge principle, guiding students to keep a keen eye on the development of technology and regional cultural industries, which is conducive to cultivating their innovative awareness and innovative ability.

\section{B. Content and Implementation of Intangible Cultural Heritage Curriculum Assessment}

Intangible cultural heritage curriculum evaluation system includes the curriculum assessment and professional skills evaluation.

\section{- Curriculum assessment}

Curriculum assessment focuses on comprehensive quality. Curriculum assessment focuses on assessing students' mastery of basic knowledge and basic skills. The assessment content is determined according to the requirements of the curriculum content of knowledge, ability and quality. The theoretical knowledge is focused on the examination of students' basic and practical knowledge. Hands-on part emphasizes to the examination of students' comprehensive qualities and professional skills. The quantitative assessment is conducted by adopting the way of combining the stage evaluation, process evaluation and curriculum assessment.

\section{- Professional skills assessment}

The operational capacity is considered as the main content of the professional skills assessment, highlighting the practice and process evaluation, and there's also the need to strengthen the cultivation of the students' ability of communication and cooperation, ability to acquire information, as well as methods and abilities. Regarding to the skill assessment, it should be conducted based on intangible cultural heritage operating skills, multi-faceted dynamic practice evaluation and comprehensive evaluation of various abilities with the combination of teaching teacher course records, as well as the progress of project tasks completed, and quality tracking, thus to test the students' comprehensive practical ability.

\section{CONCLUSION}

Mr. Luxun said: "Where there's the local characteristic, it is easy to become a world." In today's world with the continuous development of traditional Chinese culture, and multi-cultural integration, the entrance of the colorful intangible cultural heritage into the campus not only can better inherit and promote traditional culture, but also can promote the in-depth development of culture and art education in colleges and universities, thus to truly cultivate Linyi college students who are with "world feelings, Chinese soul, and Qilu characteristics".

\section{REFERENCES}

[1] Song Yongli, Zhao Benli. Analysis of Intangible Cultural Heritage of Higher Vocational Colleges into Campus [J], China Adult Education, 2014 (12): 113-114.

[2] Xiong Nana. Development and Research on School-Based Music Curriculum of Local Colleges and Universities [D], Hunan Normal University, 2013

[3] Han Teyue. Research on the Construction of Professional Curriculum System of Secondary Vocational School [J], Occupation, 2013 (11): 151-152.

[4] Zhu Dongbin. Considering Socialist Core Values as the Soul of School Moral Education from Start to End [J], moral education of primary and secondary schools, 2014 (12): 4-5.

[5] Li Wei. Significance and Implementing Research on Yao Songs in Public Music Education of Colleges and Universities in Regions with the Distribution of Yao Nationality [D], Capital Normal University, 2007.

[6] Qian Jinyi, Huang Zong, On Status and Cultivation Mechanism of Intangible Cultural Heritage Talents[J], Journal of Nanjing Institute of Arts (Fine Arts \& Design), 2013 (05): 132-137. 